\title{
Dynamic Analysis of Embankments Reinforced with Micro-Piles
}

\author{
P. Talebi ${ }^{1}$, K. Barkhordari Bafghi ${ }^{1 *}$ \\ 1- Dept. of Civil Engineering, Yazd University, Iran \\ * Corresponding Author: kbarkhordari@yazd.ac.ir \\ (Received: July 2016, Accepted: December 2016)
}

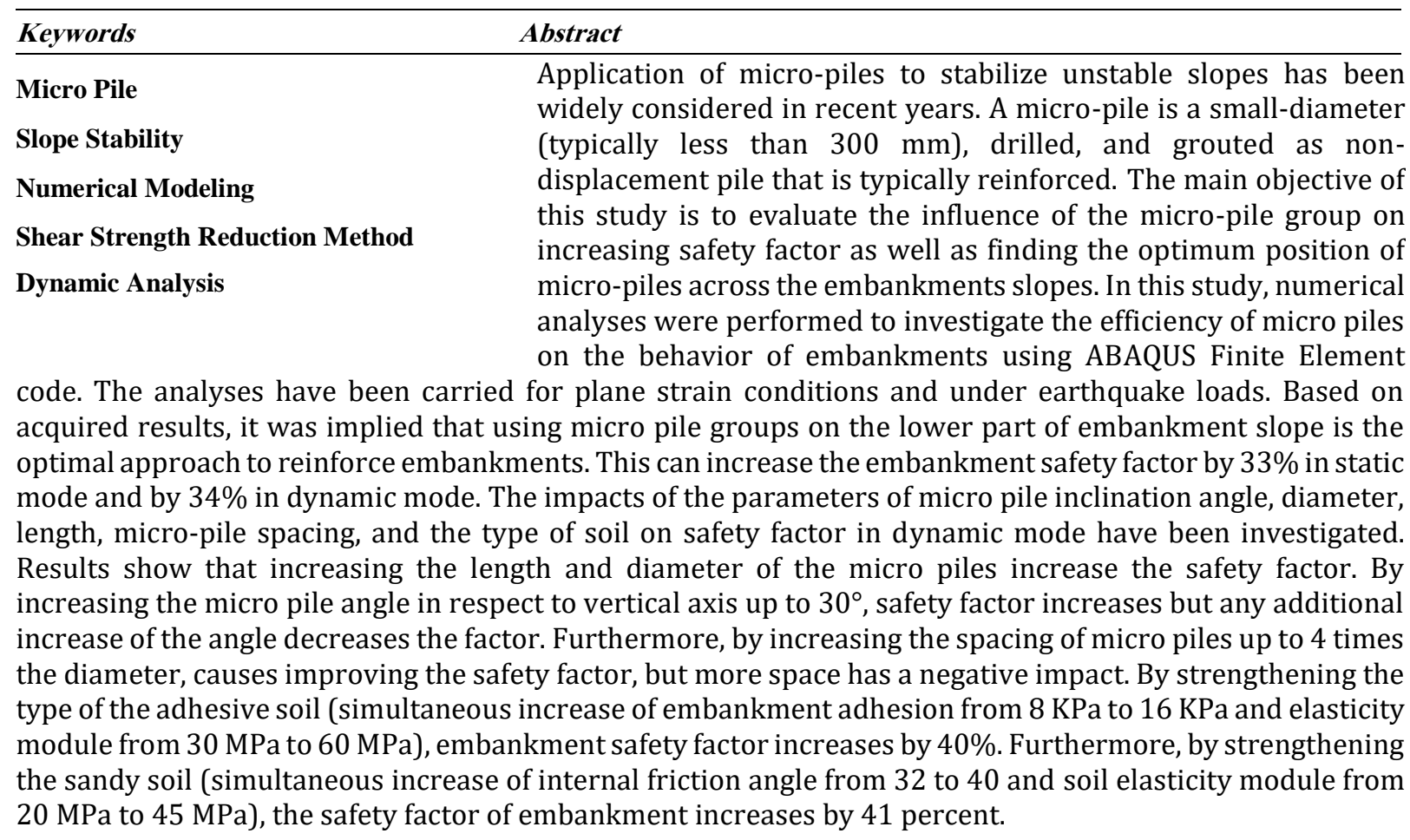

\section{INTRODUCTION}

In facing with problematic soils such as loose soil with low bearing capacity, high permeability, and soil with liquefaction potential, two approaches are common: the use of bearing elements, and modification mechanical-physical properties of the soil. Each of the above approaches has its own characteristics. Some innovative technics have combined the two approaches containing the advantages of both. Among these techniques, one can refer to the application of micro piles accompanied by grouting. In addition to functioning as a bearing element, this technique also improves mechanical properties of the soil due to grouting [1].

Micro pile is a replacement pile being accompanied by boring and grouting. Micro piles are often reinforced using steel components. They are commonly used to increase the foundations' strength against static and seismic loading, reinforcing the slopes, and stabilizing the walls of excavated areas [1]. At first, using micro piles was solely considered to improve the weak foundation of buildings. By developing this technique, the application was extended to other geotechnical areas such as stabilizing the slopes and reducing the potential of liquefaction. Presently, the instruction recommended by US.FHWA is widely accepted reference by designers and contractors in this field [2].

Recent seismic tests have shown that micro pile systems can be used in seismic areas. However, engineering data on the seismic performance of micro pile systems is limited and more research is needed to create and assess seismic designing techniques and engineering 
guidelines. Before applying micro piles as a measure to reinforce the embankments, experimental and numerical studies are required to confirm the efficiency of this method. Numerical studies conducted by engineers in recent years show the efficiency of micro piles in this application. In this regard, one can refer to the two-dimensional study of seismic behavior of micro pile groups in sandy soil conducted by Maghsoodi et al. [3] and three-dimensional elastoplastic study of the seismic performance of inclined micro piles by Sharour et al. [4]. Furthermore, employing micro pile networks in rapid excavation of a railway project by Bruce and Janes [5], investigating the stability of the slopes reinforced with micro piles by Sun et al. [6] could be mentioned in this field. Dynamic and static analysis of micro piles to reinforce high embankments of railway on loose foundation by Esmaili et al. [7], and comprehensive parametric study to achieve better perception of seismic behavior of micro piles in slopes by Elahi et al. [8] have been carried out to get better understanding of this subject.

The last paper has been used for calibration of numerical model in this study. The study is conducted for ten-meter high embankment. In present study, modeling has been performed on ABAQUS/CAE ver. 6.13-1[9], and two-dimensional analysis (plane strain) and shear strength reduction technique have been used to calculate the safety factor of the embankment. The main objective of the current study is to examine the role of micro pile in stabilizing embankments in seismic area and to determine the effect of principal parameters in embankment stabilization.

\section{MATERIAL AND METHOD}

\subsection{Embankment characteristics}

In the present study, Mohr-Coulomb constitutive model has been considered for the soil and elastic behavior has been considered for the micro pile. This model is simply a linear relationship between shear stress and vertical stress on a surface offered by Coulomb in 1773 [10]:

$$
\tau_{f}=c+\sigma \tan \phi
$$

Where, $\tau_{\mathrm{f}}$ shows shear stress, $\sigma$ shows the vertical stress onto failure surface, $\mathrm{C}$ denotes soil cohesion, and $\varphi$ is the internal friction angle of the soil. In the present study, a one-sided embankment with the height of $10 \mathrm{~m}$ and slope of 1: 1.15 has been considered (as in Fig. 1). The embankment materials are homogeneous and mostly of medium clay. Geometrical characteristics of the model and mechanical properties of the materials are presented in Tables 1 and 2 , respectively.

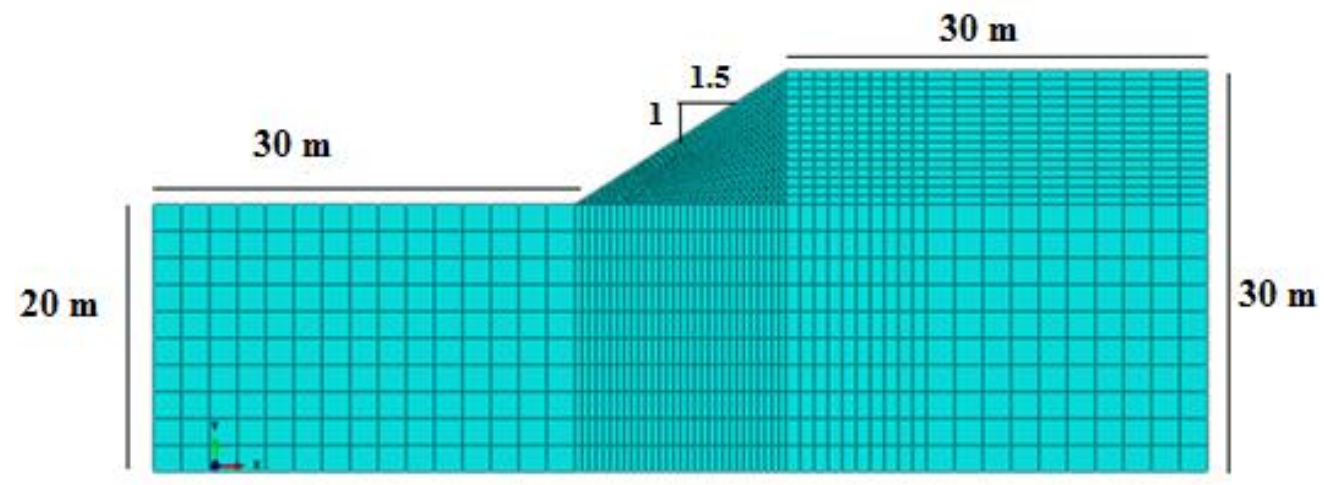

Figure 1. Geometry and mesh in model

Table1. Geometry of embankment

\begin{tabular}{|c|c|c|c|c|c|c|c|c|c|}
\hline \multicolumn{2}{|c|}{$\begin{array}{c}\text { Angle of embankment } \\
\text { (degree) }\end{array}$} & \multicolumn{3}{|c|}{$\begin{array}{c}\text { Length of the } \\
\text { embankment side (m) }\end{array}$} & \multicolumn{2}{|c|}{$\begin{array}{l}\text { Length of the bed } \\
\text { side (m) }\end{array}$} & \multicolumn{2}{|c|}{$\begin{array}{c}\text { Depth of } \\
\text { embankment }(\mathrm{m})\end{array}$} & $\begin{array}{l}\text { Depth of } \\
\text { bed(m) }\end{array}$ \\
\hline \multicolumn{2}{|c|}{33.69} & \multicolumn{3}{|c|}{30} & \multicolumn{2}{|c|}{30} & \multicolumn{2}{|c|}{10} & 20 \\
\hline \multicolumn{10}{|c|}{ Table 2. mechanical properties of the materials } \\
\hline$\gamma\left(\mathrm{kN} / \mathrm{m}^{3}\right)$ & $v$ & $\Psi\left({ }^{\circ}\right)$ & $\varphi\left({ }^{\circ}\right)$ & c (KPa) & E (MPa) & Stren & th Type & Soil Type & Model \\
\hline 20 & 0.25 & 1 & 20 & 10 & 50 & Mohr & oulomb & Clay & Embankment \\
\hline
\end{tabular}




\subsection{Determining the safety factor}

The safety factor of Slope can be defined as the reduced degree of soil shear strength when the slope has reached the critical failure mode. This is equivalent to the ratio of shear strength of the soil to reduced shear strength of the soil at failure mode. Shear strength reduction coefficient is the ratio of maximum shear strength of the slope soil to the real shear strength of the slope under external loads. Finite element method can be used to calculate shear strength reduction coefficient without determining the form and situation of the failure surface. Reduced shear strength method has firstly been used with finite element method by Zink et al. [11]. In elasto-plastic finite element analysis, based on the concept of strength reduction for a given point on the domain, MohrCoulomb criteria is defined considering the shear strength:

$$
\tau_{f}=c+\sigma \tan \phi
$$

Where $\mathrm{C}$ denotes soil cohesion and $\varphi$ is the internal friction angle of the soil. safety factor of the shear surface determined from this point is as follows [12]:

$$
F=\frac{\tau_{f}}{\tau}=\frac{c+\sigma \tan \phi}{\tau}
$$

If no shear failure occurs within the soil; then real shear stress and maximum shear strength are equal as in the following:

$$
\tau=\tau_{f m}=\frac{\tau_{f}}{F}=\frac{c+\sigma \tan \phi}{F}=C_{m}+\sigma \tan \phi_{m}
$$

Therefore, real shear stress in soils can be considered as measures of shear strength reduction. These measured are as follows:

$$
C_{m}=\frac{c}{F}, \quad \phi_{m}=\arctan \left(\frac{\tan \phi}{F}\right)
$$

First, a reduction coefficient, $\mathrm{F}$, is considered with a trial magnitude. Then, parameters of shear strength reduction are calculated according to strength reduction theory, and the final $\mathrm{F}$ is calculated [12].

\subsection{Modeling in software}

In the present study, embankment and the micro pile group have been modeled on ABAQUS/CAE Ver. 6.13-1 as two dimensional (plane strain). Since there is no pile element on this software for modeling, using the current correlations to convert micro pile Young modulus (elasticity modulus) into bar Young modulus regarding the distance of center to the center of micro piles. Micro pile rows have been modeled by equivalent bars with thicknesses as equivalent to the diameter of the micro piles according to the following relationships [13]:

$$
\begin{aligned}
& (E I)_{\text {pile }}=(E I)_{\text {wall }} \\
& E_{\text {pile }}\left(\frac{\prod D_{\text {pile }}^{3}}{64 S}\right)=E_{\text {WALL }}\left(\frac{1}{12} t_{\text {wall }}^{3}\right)
\end{aligned}
$$

In Equation 7, $E_{\text {pile }}$ is the Young (elasticity) modulus of micro pile, $D_{\text {pile }}$ is the micro pile diameter, and $\mathrm{S}$ is the center to center space (distance) of micro piles.

Load has been applied in two phases; geostatic phase to consider the in situ stresses in soil, and dynamic loading to apply earthquake load. In static mode modeling, the lower boundary of the model is constrained in vertical direction, and for the peripheral boundaries, displacement is constrained in horizontal direction. Dynamics implicit approach has been used in dynamic analysis, and dynamic loading has been applied to the model as time-displacement history at the bottom of model. For dynamic loading, accelerograms of three earthquakes; Manjil, Tabas, and Bam with 15 seconds duration have been scaled and used. Furthermore to prevent refracting waves to the model, absorbing boundary conditions have been applied. In order for modeling transient boundaries in dynamic mode, springs and viscous dampers have been employed around the model. Coefficients of the springs and dampers are related to shear wave velocity and the density of the soil layer, and are calculated through the following equations [14]:

$$
\begin{aligned}
& C=\rho v A \\
& K=\frac{8 \rho v^{2} r_{0}}{(2-\vartheta)}
\end{aligned}
$$

Where, $\mathrm{C}$ and $\mathrm{K}$ are damping coefficient nd stiffness of spring, respectively, $p$ is the density of soil mass, $A$ is the contact surface under the damper element, $r_{o}$ is half width of the element, and $v$ is shear wave velocity.

Rayleigh damping has been considered, the equations of which are described in form of matrices as in the following [15]:

$$
C=\alpha M+\beta K
$$

In Equation 10, $\mathrm{C}$ denotes damping matrix, $\mathrm{M}$ is the mass matrix, and $\mathrm{K}$ is stifness matrix. $\alpha$ and $\beta$ are damping constants.

In order to define the interaction between the two involving surfaces, the type of the interaction and the related characteristics such as friction coefficient, separation and non-separation of the 
surfaces must be defined [16]. Since the mortar penetrates into the pores of the soil during grouting, the contact between the soil and the micro pile is of Tie type.

\section{RESULTS AND DISCUSSION}

\subsection{Designing micro pile for embankments strengthening}

In order to examine the micro pile group, a group of three inclined micro piles were considered with inclination angle of $30^{\circ}$ degrees to vertical axis, center-to-center space of 4 times the micro pile diameter, and a length of $15 \mathrm{~m}, 30 \mathrm{Cm}$ of which remains outside the embankment. Due to the importance of the location of the micro pile group; micro piles were located in three different situations; namely, on the top of the slope $(\mathrm{Lx} / \mathrm{L}=0.9)$, in the mid-slope $(\mathrm{Lx} / \mathrm{L}=0.5)$, and on the slope toe $(\mathrm{Lx} / \mathrm{L}=0.1)$ so that the impact of micro pile group on increasing safety factor can be examined in different situations. $\mathrm{L}$ and $\mathrm{Lx}$ are shown in Fig. 2. Geometrical and mechanical characteristics of the micro piles are presented in Table 3.

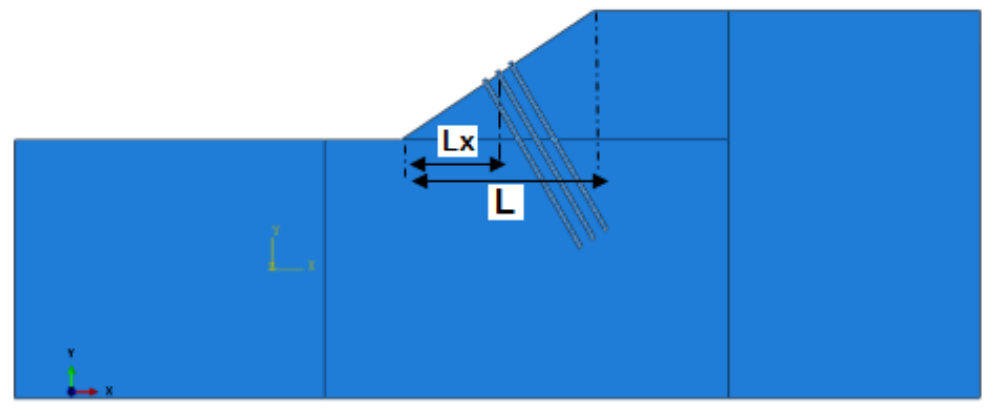

Figure 2. position of micro pile in embankment

Table3. Geometrical and mechanical characteristics the micro pile

\begin{tabular}{lccccc}
\hline & $\gamma\left(\mathbf{k N} / \mathbf{m}^{3}\right)$ & E (GPa) & $v$ & Diameter $(\mathbf{m})$ & Length $(\mathbf{m})$ \\
\hline Micropile & 26 & 4.71 & 0.2 & 0.31 & 15 \\
Bar & 78.5 & 200 & 0.2 & - & - \\
\hline
\end{tabular}

Since the micro pile is reinforced, in this study, the equivalent section has been used for modeling the micro piles. The diameter of the bar has been considered to be $4 \mathrm{Cm}$. The elasticity moduli of the concrete and the reinforcing steel have been considered to be 31 and $200 \mathrm{GPa}$, respectively. Equation 11 has been used to calculate the equivalent cross section:

$$
A_{2}=A_{1}+\left(\rho * n * A_{1}\right)
$$

Where $A_{1}$ is the primary cross section, $A_{2}$ is the equivalent cross section, and $\rho$ is the percentage of steel.

According to the above equation, the diameter of the equivalent cross section was calculated to be $31 \mathrm{Cm}$. Now, the elastic modulus should be adjusted according to Equation 7 for twodimensional analysis. On this base, for twodimensional mode on the software, elastic modulus is $4.71 \mathrm{GPa}$. The safety factor of the embankment was calculated for both modes; non reinforced and reinforced with micro pile group for different locations of the micro piles throughout the slope. Results are shown in Fig. 3 and 4 . In the case with no micro pile, according to shear strength reduction theory, since the first sharp change begins from safety factor of 1.2, it can be implied that the safety factor of the embankment in this state is 1.2. According to Fig. 3 , it can be observed that the micro piles are most effective when implemented on the slope toe $(\mathrm{SF}=1.6)$.

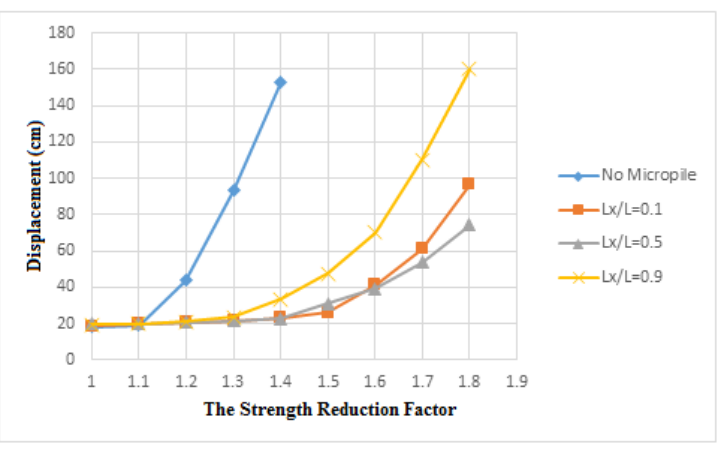

Figure 3. comparing the impact of micro pile group on increasing safety factor in static mode

At next when micro piles were located on the mid-slope ( $\mathrm{SF}=1.5)$, and finally, implementing the 
micro piles on the top of the slope had the lowest impact on improving the safety factor $(\mathrm{SF}=1.4)$.

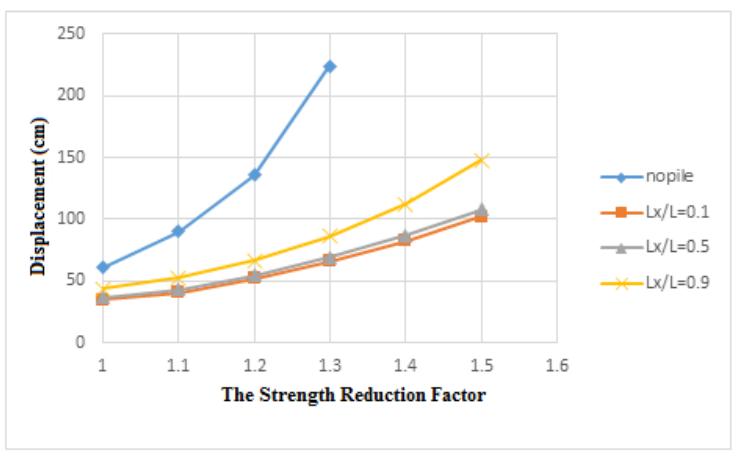

Figure 4. comparing the impact of micro pile group on increasing safety factor in seismic mode

In order for more accurate study of the impacts of micro piles on increasing embankment stability, this study must be carried out based on the maximum allowable displacement of the embankment. According to USACE engineer manual, this amount is 50 to $150 \mathrm{~cm}$; hence in the present study, these changes have been considered for maximum allowed displacement of 50 and $100 \mathrm{~cm}$ (Table 4).

In the current study, the optimal safety factor was achieved when the micro piles were implemented at $(\mathrm{Lx} / \mathrm{L}=0.1)$; therefore, parametric studies are conducted for this section. The characteristics of the embankment and micro pile in this model are the same as those in the model discussed in previous sections.

Table 4. changes of the safety factor vs. allowable displacement

\begin{tabular}{|c|c|c|c|c|}
\hline \multirow{3}{*}{$\begin{array}{l}\text { allowable } \\
\text { Displacement of } \\
\text { Embankment } \\
\text { (cm) }\end{array}$} & \multicolumn{4}{|c|}{ Safety Factor } \\
\hline & \multicolumn{3}{|c|}{ With Micro pile Group } & Micro \\
\hline & $\begin{array}{c}(\mathrm{Lx} / \mathrm{L}= \\
0.1)\end{array}$ & $\begin{array}{c}(\mathrm{Lx} / \mathrm{L}= \\
0.5)\end{array}$ & $\begin{array}{c}(\mathrm{Lx} / \mathrm{L}= \\
0.9)\end{array}$ & \\
\hline 50 & 1.2 & 1.15 & 1.08 & Failure \\
\hline 100 & 1.5 & 1.46 & 1.35 & 1.12 \\
\hline
\end{tabular}

\subsection{Investigating the impact of inclination angle of the micro piles on slope stability}

By varying the micro pila angle to the vertical axis within the range $\theta=0^{\circ}$ to $\theta=75^{\circ}$ while other variables remain constant, the impact of this angle on increasing safety factor can be examined in seismic mode for 50 and $100 \mathrm{Cm}$ displacements. Fig. 5 illustrates the impact of inclination angle of micro pile on stability of embankment under earthquake loading. As it can be implied from the diagram, the highest safety factor corresponds to inclination angle of $30^{\circ}$. By increasing the angle up to $30^{\circ}$, the seismic performance of the micro piles is improved. In this case, the safety factor is 1.2 for allowable displacement of $50 \mathrm{~cm}$ and 1.5 for displacement of $100 \mathrm{~cm}$. Using greater inclination angles (greater than $30^{\circ}$ ) in implementing micro piles leads to increased displacement and decreased safety factor.

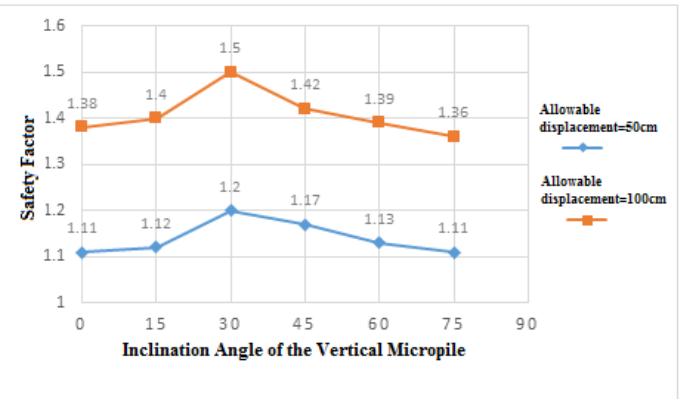

Figure 5. comparing the impact of micro pile angle on safety factor

\subsection{Investigating the impact of micro pile spacing on slope stability}

Micro pile spacing can be considered as one of the most important factors in effectiveness of the micro pile group. This factor is defined as the ratio of space to the diameter. $\mathrm{S}$ is the center to center space of the micro pile and D is the micro pile diameter. In this study, the impact of spacing on slope stability has been examined by keeping the number of rows of micro piles as constant while varying the spacing of the micro pile rows. According to FHWA regulations, micro piles spacing for embankment stabilization must be 3 to 7 times the diameter of the micro piles. In the current study, micro pile spacing has been considered as being 2 to 6 times the diameter of the micro piles.

Fig. 6 highlights the impact of the space between the rows of micro piles on safety factor. As it can be perceived from the diagram, the optimal space between the micro piles is 4 times the diameter, where the embankment safety factor is 1.2 for displacement of $50 \mathrm{Cm}$ and 1.5 for displacement of $100 \mathrm{Cm}$. When micro pile spacing is 2 to 3 times the diameter, their impact on reliability safety factor is fixed (not improved) due to overlapping, but when this space is increased to 4 times the diameter, the safety factor is significantly improved as discussed before. However, for greater spacing (beyond 4 times the diameter) the safety factor is decreased. 


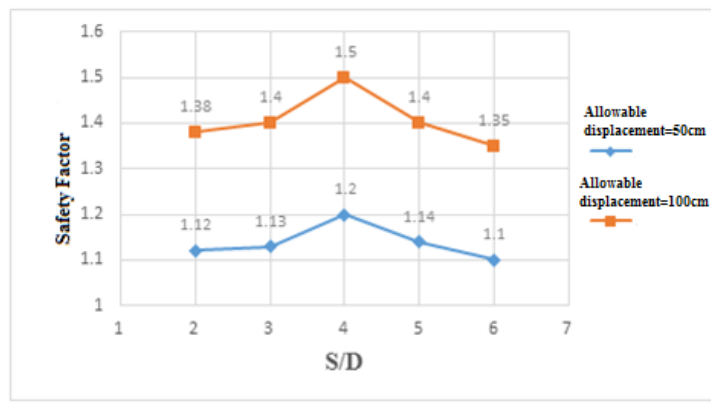

Figure 6. Impact of micro pile spacing on safety factor

\subsection{Investigating the impact of micro pile diameter on slope stability}

In this study, the impact of micro pile diameter on reliability has been examined in seismic mode for $50 \mathrm{~cm}$ and $100 \mathrm{~cm}$ displacements by varying the diameter of the micro piles within the range of $\mathrm{d}=10 \mathrm{~cm}$ and $\mathrm{d}=30 \mathrm{~cm}$ while other variables remain constant. Fig. 7 shows the impact of micro pile diameter on safety factor under Manjil earthquake loading. As it can be seen from the diagram, by increasing the diameter, the safety factor is increased. Increasing the diameter leads to increased stiffness; resulting in increased stifness of the embankment. As a result, embankment displacement is reduced while safety factor is increased. In fact, in case of $50 \mathrm{~cm}$ displacement, the safety factor is 1.11 for $d=10 \mathrm{~cm}$ and 1.2 for $\mathrm{d}=30 \mathrm{~cm}$. furthermore, in case of 100 $\mathrm{Cm}$ displacement, safety factor is 1.38 for $\mathrm{d}=10 \mathrm{~cm}$ and 1.5 for $\mathrm{d}=30 \mathrm{~cm}$.

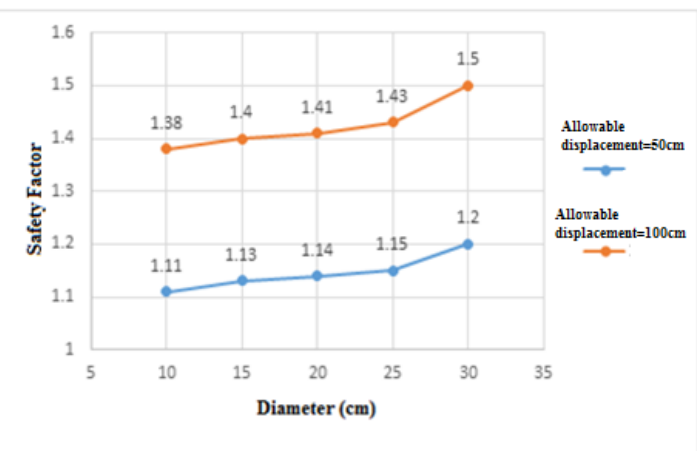

Figure 7. Impact of micro pile diameter on safety factor

\subsection{Investigating the impact of micro pile length on slope reliability}

Micro pile length must be set out in a way to pass critical slip surface. Lateral resistance capacity of the micro pile below the slip surface should be great enough to resist the forces imposed on this section. In the present study, the impact of micro pile length on safety factor has been examined for 50 and $100 \mathrm{~cm}$ displacements by varying the length within the range $\mathrm{L}=5 \mathrm{~m}$ and $\mathrm{L}=20 \mathrm{~m}$ while other variables remain constant.

Fig. 8 shows the impact of micro pile length on safety factor. As it can be observed from the diagram, by increasing the length of micro piles, the safety factor is increased. Therefore when the micro pile length is increased from $5 \mathrm{~m}$ to $20 \mathrm{~m}$, embankment safety factor is increased from 1.1 to 1.25 for $50 \mathrm{~cm}$ displacement, and from 1.4 to 1.55 for $100 \mathrm{~cm}$ displacement.

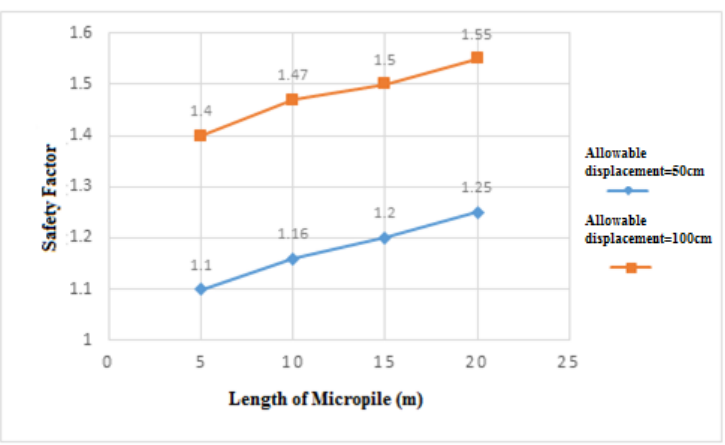

Figure 8. Impact of micro pile length on safety factor

\subsection{Varying the parameters of cohesive soils}

Cohesion is one of the most important parameters of shear strength; therefore in this study, six types of soil were selected as varieties within the range of soft, average and hard clay according to the standard classification of USACE and Iranian Office of Coastal and Marine Engineering [17, 18]. The micro pile group was implemented on the slope toe $(\mathrm{Lx} / \mathrm{L}=0.1)$ containing three inclined micro piles with inclination angle of $30^{\circ}$ to the vertical axis, centerto-center spacing of 4 times the diameter, and a length of $15 \mathrm{~m}, 30 \mathrm{~cm}$ of which remained outside the soil. Table 5 presents the characteristics of the soils used in this study. Soil 1 is regarded as having undergone failure with $50 \mathrm{~cm}$ displacement; therefore, this micro pile group is not appropriate for soils with such properties, and the number of micro piles must be increased.

Fig. 9 shows the safety factor corresponding to soils 2 to 6 . As it is apparent from the diagram, with an increase in cohesion, and relatedly elasticity modulus of soil the safety factor is also increased. In fact, when the internal friction angle is considered fixed as being $20^{\circ}$, and embankment cohesion is increased from $8 \mathrm{KPa}$ to $16 \mathrm{KPa}$, and the elasticity modulus is increased from $30 \mathrm{MPa}$ to 60 $\mathrm{MPa}$, embankment safety factor is increased by 40 percent for a $50 \mathrm{~cm}$ displacement. 
Table 5. characteristics of cohesive soils used in the study

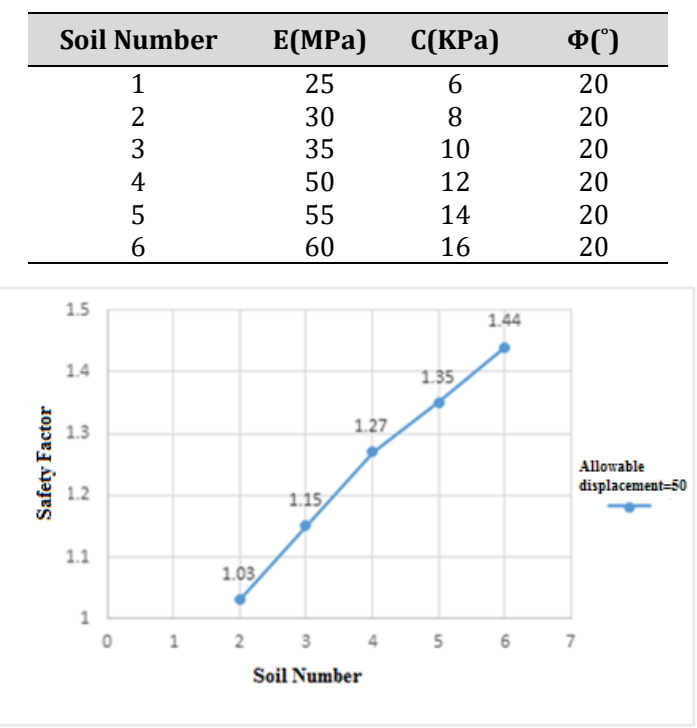

Figure 9. Comparing the impact of type of soil on safety factor

\subsection{Varying the parameters of sandy soils}

In this study, six types of soil were selected as categories within the range of soft, average and hard sandy soils [19-21]. The micro pile group was utilized on the slope toe $(\mathrm{Lx} / \mathrm{L}=0.1)$ containing three inclined micro piles with inclination angle of $30^{\circ}$ to the vertical axis, center-to-center spacing of 4 times the diameter, and a length of $15 \mathrm{~m}, 30 \mathrm{~cm}$ of which remained outside the soil. Table 6 presents the characteristics of the soils used here. Soil 1 is regarded as having undergone failure with a $50 \mathrm{~cm}$ displacement; therefore, this micro pile group is not appropriate for reinforcing soils with such properties, and some modifications are required such as increasing the number of micro piles.

Table 6. characteristics of sandy soils used in the study

\begin{tabular}{ccccc}
\hline Soil Number & $\vartheta$ & $\mathrm{E}(\mathrm{MPa})$ & $\Psi\left({ }^{\circ}\right)$ & $\Phi\left(^{\circ}\right)$ \\
\hline 1 & 0.25 & 6.5 & 1 & 28 \\
2 & 0.3 & 20 & 2 & 32 \\
3 & 0.3 & 28 & 4 & 34 \\
4 & 0.35 & 35 & 6 & 36 \\
5 & 0.35 & 40 & 8 & 38 \\
6 & 0.35 & 45 & 10 & 40 \\
\hline
\end{tabular}

Fig. 10 shows the safety factor corresponding to soils 2 to 6 . As it is apparent from the diagram, with an increase in soil stiffness, the safety factor is also increased. The soil with greater friction angle mobilizes more friction. Micro piles implemented in soils with greater friction angle bear greater displacements reducing embankment displacement. Indeed when the internal friction angle of the embankment is increased from $32^{\circ}$ to $40^{\circ}$ and the elasticity modulus is increased from $20 \mathrm{MPa}$ to $45 \mathrm{MPa}$, the embankment safety factor increases by 41 percent for a $50 \mathrm{~cm}$ displacement.

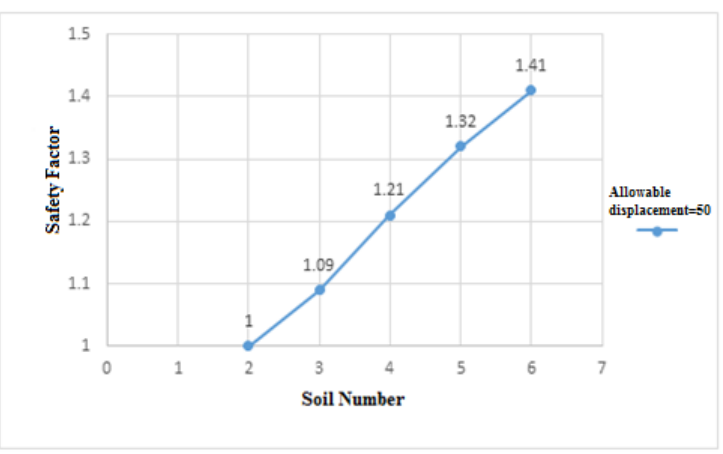

Figure 10. comparing the impact of type of sandy soil on safety factor

\section{CONCLUSION}

This study has been carried finite element method using ABAQUS software to perform investigations on reinforcement of embankments (10 $\mathrm{m}$ high) using micro pile group (containing three micro piles with center-to-center spacing of 4 times the diameter, a length of $15 \mathrm{~m}$, and a diameter of $30 \mathrm{~cm}$ ) in dynamic and static modes, the results of which are as follows:

\section{- The impact of micro pile location in static mode}

Implementing the micro pile group at the slope toe the embankment safety factor increased by 33 percent; at the mid-slope increased by 25 percent, and on the top of the slope increased by 16 percent. On this base, the best location for the micro pile group in static mode is at the slope toe.

\section{- The impact of micro pile location in dynamic mode}

\section{For a $50 \mathrm{~cm}$ displacement:}

Implementing the micro pile group on the top the embankment safety factor increased by 16 percent, at the mid-slope increased by 23 percent, and at the slope toe increased by 25 percent.

\section{For a $100 \mathrm{~cm}$ displacement}

The safety factor is increased by 20 percent when micro pile group are applied on the top increased embankment, and increased by 30 percent for micro piles at the mid-slope, and increased by 34 percent for micro piles at the at the slope toe. 
Based on the results, it is best to implement the micro pile group at the slope toe to reinforce embankments for dynamic loading.

\section{- $\quad$ Parametric studies in dynamic mode}

By increasing the inclination angle of the micro piles up to $30^{\circ}$ from the vertical axis, embankment displacement is decreased and safety factor is increased, but using angles greater than $30^{\circ}$ leads to decreased safety factor of the embankment. Therefore, an inclination angle of $30^{\circ}$ is most effective in increasing slope stability.

By increasing the micro piles spacing up to 4 times the diameter, embankment displacement is decreased and safety factor is increased. However, increasing the spacing above 4 times the diameter reduces the effects of the micro pile group leading to increased displacement and decreased safety factor.

By increasing the micro pile diameter from 10 $\mathrm{Cm}$ to $30 \mathrm{Cm}$, micro pile cross section and stiffness are increased resulting in decreased embankment displacement. In fact for a $50-\mathrm{Cm}$ displacement, safety factor is increased from 1.11 to 1.2 , and for a $100-\mathrm{Cm}$ displacement, it is increased from 1.38 to 1.5 .

Increasing the micro pile length from $5 \mathrm{~m}$ to 20 $\mathrm{m}$ increases the safety factor for $50 \mathrm{Cm}$ displacement from 1.1 to 1.25 and for $100 \mathrm{Cm}$ displacement from 1.4 to 1.55 . This is due to increased cross section of the micro piles and decreased displacement of the embankment.

Since increasing the soil cohesion decreases embankment displacement, it increases the safety factor. By increasing the embankment cohesion from $8 \mathrm{KPa}$ to $16 \mathrm{Kpa}$ and simultaneous increase in elasticity modulus from $30 \mathrm{MPa}$ to $60 \mathrm{MPa}$, the embankment safety factor is increased by 40 percent.

By increasing the internal friction angle from $32^{\circ}$ to $40^{\circ}$ and simultaneous increase of soil elasticity modulus from $20 \mathrm{MPa}$ to $45 \mathrm{MPa}$, the safety factor of the embankment is increased by 41 percent. Micro piles implemented in soils with greater friction angle bear greater displacements reducing embankment displacement and increasing the safety factor.

Based on the above results, implementing the micro piles at the slope toe is the best optimal strategy to reinforce the embankment through optimizing mechanical and physical characteristics of the soil and the bed, attaching soil layers to each other, and transmitting the applied loads. Using the maximum micro pile diameter can reduce the number of required micro piles, which in turn reduces the construction costs. Inclination of the micro piles can enhance their performance. The optimal inclination angle for the micro piles is $30^{\circ}$, and the best spacing is set as 4 times the micro pile diameter.

\section{REFERENCES}

[1] Bruce, D.A., Jurnan, I. and Dimillio, A.F., (2001), "High Capacity Grouted Micro piles: The State of Practice in the United State", Geotechnical Special Publication No. 90, (edited by G. Fernandez and R.A. Bauer). ASCE, Reston, Virginia. pp. 188199.

[2] Sun, Sh., Wang, W. and Zhao, F., (2014), "Three-Dimensional Stability Analysis of a Homogeneous Slope Reinforced with Micro pile" Hindawi Publishing Corporation Mathematical Problems in Engineering, Article ID 864017.

[3] Maghsoodi, V., Atermoghaddam, F. and Esmaeili-Falak, M., (2013), "Parametric and two dimensional study of seismic behavior of micro pile group in sandy soil” Intl. Res. J. Appl. Basic. Sci. Vol., 6 (7), 901-909, 2013.

[4] Shahrour, I., Alsaleh, H. and Souli, M., (2012), "3D elastoplastic analysis of the seismic performance of inclined micro piles", Computers and Geotechnics 39 1-7.

[5] Bruce, J. and Janes, M., (2014) "A Case 2 Micro pile Network Employed at a Rapid Excavation Railway Project" 12th International Workshop on Micro pile June $11^{\text {th }}$ to $14^{\text {th }}$, Krakow, Poland. GeoFoundations Contractors Inc.

[6] Esmaeili, M., Ghorbani Nik, M. and Khayyer, F., (2013), "Efficiency of Micro Piles in Reinforcing Embankments", Proceeding of the Institution of Civil Engineers Ground Improvement 167, Issue GI2 Pages 122-134

[7] Elahi, H., Elahi, A. and Hajmolaali, H., (2013), "A Parametric Study on Seismic Behavior of Pile Group Located in Soil Slope", the $1^{\text {st }}$ Iranian Conference on Geotechnical Engineering, 22-23. University of Mohaghegh Ardabili, Ardabil, Iran.

[8] Leonie, M., (2005), "Implementation and Use of Constitutive Models in Geomechanicss: Analysis of Shallow Footings on Sand", Head of the Ph.D. Programe in Geotechnical Engineering: Prof. Gian Paolo Giani.

[9] ABAQUS, Inc. "ABAQUS version 6.11 user's manual". 
[10] He, B. and Zhang, H., (2012), "Stability Analysis of Slope Based on Finite Element Methode", Engineering and Manufacturing, No.3, 70-74.

[11] Zienkiewicz, O. C. \& Taylor, R. L. (1989). The finite element method, Vol. 1, 4th Ed. London, New York: McGraw-Hill.

[12] Schroeder, F.C., Potts, D.M. and Addenbrooke, T.L., (2004), "The Influence of Pile Group Loading on Exiting Tunnel”, Geotechnique 54, No.6, 351-362.

[13] Wolf, J., and Deeks, A., (2002), "Foundation Vibration Analysis: Strength-of Materials Approach". Elsevier Linacre House, Jordan Hill, Oxford OX2 8DP 200 Wheeler Road, Burlington, MA 01803.

[14] Dasgupta, S.P., (2008) "Computation of Rayleigh Damping Coefficient for System", Department of Civil Engineering Indian Institute of Technology Kharagpur 721302, India.

[15] Dutta, S.Ch. and Roy, R., (2002), “A Critical Review on Idealization and Modeling for Interaction among Soil-Foundation-Structure System", Computers and Structures 801579 1594.

[16] Office of Deputy for Strategic Supervision (2013) "Guideline for Seismic Analysis and Design of Earth \& Rock fill Dams" Technical publication NO. 624 Office of Deputy for Strategic Supervision Department of Technical Affairs (In Persian).

[17] Ports and Maritime Office. (2014). "Bylaw Designed Marine Structures Iran". Office of Coastal and Marine Engineering (In Persian).

[18] USACE Engineer Manual (1990). "EM 1110-1-1904, Engineering and design-Settlement Analysis".

[19] Wolf, T.F. (1989). "Pile Capacity Prediction Using Parameter Functions". Geotechnical Engineering Division, ASCE, Geotechnical Special Publication No. 23, pp. 96106.

[20] Kulhawy, F. H.; Mayne, P. W. (1990). "Manual of Estimating Soil Properties for Foundation Design". Electric Power Research Institute, Palo Alto, California.

[21] Meyerhof, G. G. (1956). "Penetration Tests and Bearing Capacity of Cohoesionless Soils". Journal of Soil Mechanics and Foundation Division, ASCE. Vol. 82, No. SM1, pp 1-19. 